\title{
ARCHIVE*
}

In the interwar years, social sciences developed in East Central Europe along with nation-states and their increasingly apparent weaknesses. Polish sociologists of the period, whose intellectual formation dated back to the last decades of the European empires, coped with the challenges of their time and commented on modern ideologies, mass movements, sudden social dislocations, and economic depressions. Stefan Czarnowski (1879-1937), a member of the Durkheim school and a disciple of Henri Hubert (1872-1927) and Marcel Mauss (1872-1950), was one of them. A historian of culture, he specialised in Celtic history and was among the founding fathers of Polish sociology. ${ }^{1}$ His outstanding works include Le culte des héros et ses conditions sociales: Saint Patrick, héros national de l'Irlande; ${ }^{2}$ a collection of essays published posthumously as Kultura [Culture], ${ }^{3}$ and a methodological study Założenia metodologiczne w badaniu rozwoju społeczeństw ludzkich [Methodological

* The work on this introduction was supported by NPRH grant no. 0133/ NPRH4/H1b/83/2015.

${ }^{1}$ For a complete edition of Stefan Czarnowski's works, see Stefan Czarnowski, Dzieta, 5 vols., ed. by Nina Assorodobraj and Stefan Ossowski (Warszawa, 1956). German scholar Max Spohn is presently working on a first complete intellectual biography of Czarnowski. The existing reliable discussions include: Nina Assorodobraj, 'Życie i dzieło Stefana Czarnowskiego', in Czarnowski, Dzieła, v, 105-56; Marek Jabłonowski (ed.), Stefan Czarnowski z perspektywy siedemdziesięciolecia (Warszawa, 2008); Kornelia Kończal and Joanna Wawrzyniak, 'Posłowie'/'Postface', in Stefan Czarnowski, Listy do Henri Huberta i Marcela Maussa (1905-1937) / Lettres à Henri Hubert et à Marcel Mauss (1905-1937), ed. by Kornelia Kończal and Joanna Wawrzyniak, trans. by Filip Rogalski and Damien Thiriet (Warszawa, 2015), 173-220, 358-405; Małgorzata Legiędź-Gałuszka, Czarnowski (Warszawa, 1989); Marian Małowist, 'Stefan Czarnowski (1879-1937)', in Aleksander Gieysztor, Jerzy Maternicki, and Henryk Samsonowicz (eds.), Historycy warszawscy ostatnich dwóch stuleci (Warszawa, 1986), 231-44; Janina Markiewicz-Lagneau, La Formation d'une pensée sociologique. La société polonaise de l'entre-deux-guerres (Paris, 1982), 187-241; Róża Sułek, 'Droga Stefana Czarnowskiego do katedry socjologii w Uniwersytecie Warszawskim', in Antoni Sułek (ed.), Socjologia na Uniwersytecie Warszawskim. Fragmenty historii (Warszawa, 2007), 97-100; Jerzy Szacki, Sto lat socjologii polskiej. Od Supińskiego do Szczepańskiego. Wybór tekstów (Warszawa, 1995), 95-9.

${ }^{2}$ Stefan Czarnowski, Le Culte des héros et ses conditions sociales. Saint Patrick, héros national de l'Irlande, preface by Henri Hubert (Travaux de L'Année sociologique, 6, Paris, 1919).

${ }^{3}$ Stefan Czarnowski, Kultura, foreword by Ludwik Krzywicki (Warszawa, 1938). 
assumptions behind research into the development of human societies], which was a part of his never-finished book on general sociology. ${ }^{4}$ The interwar years saw Czarnowski lecture at the Higher School of Warfare, the Free Polish University, and the Conservatory of Music before he was offered, in 1930, the chair of History of Culture at the University of Warsaw (renamed since 1934 as the chair of Sociology and History of Culture). As was the case with a number of his colleagues, Czarnowski for most of his life willingly assumed the role of a public intellectual, publishing essays or commentaries in Tygodnik Polski (1911-12) and, after the Second World War, in Kurier Polski and Robotnik (to name but two). His involvement in public affairs directly inspired his article on 'Redundant People in the Service of Violence' (1935), a translation of which is published in this issue.

Admittedly, the evolution of Czarnowski's own political views was quite thorough. Connected as a young man with the Association of the Polish Youth 'ZET' (National Democracy's youth organisation), he subsequently joined a 'Secesja' group which in 1911 left the ranks of the National Democrats as a token of protest against Roman Dmowski's pro-Russian policy. During the Great War, Czarnowski supported the political line pursued by Wtadysław Sikorski and the Austrian-affiliated wing of the Polish Legions, with which he served as a recruitment officer. During the Polish-Bolshevik war, he commanded a Polish infantry unit and, in this capacity, took part in heavy combat operations in Ukraine. In the 1920s, disillusioned with the political situation of the time, he declared himself a resolute opponent of National Democracy; yet, he was not an adherent of Józef Pitsudski's politics - particularly regarding the Coup of May 1926 and the Sanacja regime. ${ }^{5}$ As he wrote in September 1928 to Marcel Mauss, "Mussolini and Primo de Rivera would have been enough for me. The atmosphere in Poland is becoming stifling." 6

In 1929, Czarnowski joined the Polish Socialist Party (PPS). While he never before had been on close terms with this organisation, he did this as a gesture of support for the parliamentary opposition when their confrontation with the government camp had grown more and more strained. All the same, his views became radical after the arrests and trial of members of the center-left opposition in 1930-2, the pacification actions against the

${ }^{4}$ Stefan Czarnowski, 'Założenia metodologiczne w badaniu rozwoju społeczeństw ludzkich', in Dzieła, ii, 197-221.

5 Tomasz Nałęcz, 'Jeden z pokolenia niepokornych', in Jabłonowski (ed.), Stefan Czarnowski, 57, 59.

${ }^{6}$ [Letter to Marcel Mauss, 11 Sept. 1928], in Czarnowski, Listy, 150. 
Ukrainian minority (1930), and Hitler's coming to power in Germany; other reasons for his radicalization included the rise of anti-Semitic attitudes in public life and, above all, the Great Depression that lasted in Poland until 1935. ${ }^{7}$ Czarnowski quit the PPS ranks in 1931 and explained his reasoning in an 'Open Letter' published in an occasional leaflet Robotnik Socjalista ['The Socialist Worker'] in February 1932. There he criticised the democratic and parliamentary ideals of the Party, arguing that its policy only favoured the bourgeoisie, who sought "a system in which the working masses would be completely dependent upon the possessing classes: namely, Fascism." According to Czarnowski "Economic nationalism generates favourable conditions for [fascism's] development: the bourgeoisie have the inflexible will to bring it about. ... Should the proletariat be entertained merely with ballot pranks and arbitration procedures; should they continuously be rocked to sleep by the opportunistic policies of the Second International - then, what is threatening them is an awakening in fetters from which they will not get liberated for a whole century." 8

Hence, the communist movement was for Czarnowski a real option against fascism. He kept in touch with members of the Communist Party of Poland (KPP), though the nature of his association with this organisation has remained unclear. ${ }^{9}$ In June 1933, he took part in a European Anti-Fascist Congress in Paris. Also, he pledged support for forming a people's front to resist the radical rightist parties on their way to seize power, a policy proposed by the Seventh Congress of the Communist International. ${ }^{10}$ His relationship with the communists was facilitated by a reorientation of his scholarly outlook: he had made Marxism part of his own research method. At Warsaw University, he acted as a mentor to the 'socialist youth' group, alongside his activities as promoter of student research on the conditions of labour and life among the young generation in Poland. Outside the University, he lectured for printers and workers, ${ }^{11}$ and he established contacts with left-wing teachers as a co-founder of the Society for Democratic Education 'Nowe Tory' ('New Track'), a tutor of graduation theses with the State Institute of Teachers, and a member of the Polish Teachers' Association. He was, moreover, among the founders of Głos Współczesny, a magazine for teachers who sympathised with the people's

${ }^{7}$ Nałęcz, 'Jeden z pokolenia niepokornych', 60-2; Sułek, 'Droga Stefana Czarnowskiego', 78-80.

${ }^{8}$ Stefan Czarnowski, 'List otwarty', in Dzieła, v, 53-4.

${ }^{9}$ Nałęcz, 'Jeden z pokolenia niepokornych', 64-5.

${ }^{10}$ Ibidem.

${ }^{11}$ Sułek, 'Droga Stefana Czarnowskiego', 79. 
front. It was in this periodical that his essay on 'redundant people' [original title, Ludzie zbędni w służbie przemocy] was originally published. ${ }^{12}$

In his essay, Czarnowski applied a comparative method typical of his academic outlook, inspired by his former collaboration with Henri Hubert. Rather than for the sake of flaunting erudition, the essay referred to various historical examples in order to derive a universal societal phenomenon on the basis of those examples. Czarnowski argued for the general existence of groups who were not firmly anchored in the social structure and were easy to mobilise for violent actions. Then he made a reference to the situation of his contemporary Poland in order to demonstrate how dangerous the jobless people were for public life - in his opinion, they were easy meat for the radical Right.

The threat of fascism, intertwined with the effects of the Great Depression, was, according to Czarnowski, reinforced in Poland owing to specific institutional solutions. The essay's important subtext was his reaction to the reforms in the sectors of insurance and education, which were intensely disputed at the time. The social insurance law adopted in 1933 unified the formerly diverse legislation of Russia, Germany (Prussia) and Austria, into a consistent legal regime. Yet, this 'consolidating law' was enacted when the economic crunch was at its hardest. Insurance against unemployment among industrial workers was not covered by the act, probably for fear of financial incapacity in the responsible insurance institution. The measures undertaken in view of alleviating the effects of unemployment were designed as a separate instrument of governmental administration and were still covered by separate and insufficient legislation passed in 1924:13 a solution that outraged Czarnowski. As part of his comment, he found that "the average unemployed person considers him or herself a regular member of society ... as long as one receives an allowance not as alms but as an entitlement".

Educational reform was the other issue that triggered emotional reactions among the leftists. Launched in 1919, compulsory schooling regulation introduced an obligatory seven-grade common (primary) school for children aged seven to fourteen. Although the decree was meant to be gradually implemented,

${ }^{12}$ Gtos Wspótczesny was issued only in 1935; cf. Bronisław Ługowski and Eugeniusz Rudziński, Polska lewica społeczna wobec oświaty w latach 1919-1939. Wybór materiatów (Warszawa, 1960), 478.

${ }^{13}$ Jan Nowacki, 'Ubezpieczenie na wypadek braku pracy', in Rozwój ubezpieczeń spotecznych $w$ Polsce (Wrocław, 1991), 151-5; Antoni Malaka, 'Ustawa scaleniowa - okoliczności jej uchwalenia i znaczenie dla rozwoju ubezpieczenia społecznego', in Ubezpieczenie spoteczne dawniej $i$ dziś. W 80-lecie uchwalenia ustawy o ubezpieczeniu spotecznym (Wrocław, 2013), 7-24. 
the situation in the field of education remained diverse throughout the two interwar decades. In developed western provinces, primary teaching covered almost all of the children; more than a half were covered in the central voivodeships; and only a third in the eastern regions of Poland. In the countryside, one-teacher schools, unable to meet the general curricula requirements, were not a rarity. The reform of the school system which was introduced in 1932 preserved the seven-year compulsory education system and the organisational and curricula diversity of primary schools was legally sanctioned. Paid education at the secondary and tertiary levels was retained. As a result, the differences between rural and urban environments, and between the indigent and affluent strata of society, were becoming calcified. Graduation from a rural school basically opened no access to higher levels of education. In urban areas, access to secondary schools was conditional upon the parents' income. The extensive rural economy, where child labour was common, and a shortage of teachers and classrooms caused significant numbers of children (in excess of 900,000 as of 1934/5) not to meet the compulsory education requirement. The bill proposed mechanisms to enhance the standard of vocational education, but in Czarnowski's opinion, this implied a threat that hosts of the undereducated youth would enter the labour market and public life. ${ }^{14}$

The subsequent issue of Głos Współczesny published Czarnowski's essay on 'Anti-Semitic riots at universities', which, in a sense, followed up on the 'redundant people' article. Here, the author responded to violent acts committed against Jews by the National Radical Camp (ONR), and protested against a passive attitude towards those actions displayed by a large number of faculty members. Czarnowski pointed out that 'staff managers' of the fascist movement were being recruited among Polish students: "The thing is, the officials, teachers, barristers, and physicians-to-be are meant to be 'nationalists'", he wrote, remarking that the movement would be favoured by masses of poor student youth: they would not resist due to their social situation or merely out of conformity. ${ }^{15}$

With time, the essay on 'redundant people' became a classic in Polish social sciences and humanities. One may quote in this context the opinion of Jerzy

14 Bronisław Ługowski, Szkolnictwo w Polsce 1929-1939 w opinii publicznej (Warszawa, 1961); Jarosław Jastrzębski, 'Reforma Jędrzejewicza w państwowym szkolnictwie akademickim II Rzeczypospolitej. Wzmocnienie prerogatyw władz państwowych', Zeszyty Naukowe Uniwersytetu Jagiellońskiego. Prace Historyczne, 138 (2011), 159-76.

${ }^{15}$ Stefan Czarnowski, 'Zajścia antysemickie w szkołach wyższych', Głos Wspótczesny, 2 (1935), 19-24. 
Szacki, the historian of sociological thought, who found Czarnowski's article particularly noteworthy because it showed the relationship between social science and current politics, along with the author's ability to discover general social mechanisms on the basis of observations of concrete phenomena. The essay under discussion offers interesting remarks related to the historical role of marginalised social groups - though such reflections were perhaps not quite original, given the considerations proposed by Georg Simmel (1858-1918) or the Chicago School in sociology, to which Czarnowski refers in his text, specifically mentioning Frederic M. Thrasher (1892-1962). ${ }^{16}$ Detached from its original political context, Czarnowski's 'redundant people' concept has all the same proved to be rather fertile as it originated a series of important historical studies, including Czarnowski's disciple Nina Assorodobraj's research on the origins of the working class in Poland. ${ }^{17}$ Above all, however, 'redundant people' has become a figure of speech in Polish sociology and public discourse. Recently, it has been used by Zygmunt Bauman in his book, Wasted Lives, on social exclusion under the contemporary wave of globalisation. ${ }^{18}$

Joanna Wawrzyniak

trans. Tristan Korecki

copyediting Aaron Law

${ }^{16}$ Szacki, Sto lat socjologii, 98. Czarnowski discussed Thrasher's The Gang: A Study of 1,313 Gangs in Chicago (Chicago, 1927) at his seminar; inspired by the book, Nachuma Tenenbaum, a student of his, wrote her MA dissertation on juvenile crime in Warsaw (submitted in 1933); cf. Sułek, 'Droga Stefana Czarnowskiego', 86.

${ }^{17}$ Nina Assorodobraj, Poczatki klasy robotniczej. Problem rąk roboczych w przemyśle polskim epoki stanisławowskiej, foreword by Józef Chałasiński (Warszawa, 1946).

${ }^{18}$ Zygmunt Bauman, Wasted Lives: Modernity and Its Outcasts (Cambridge, 2003). 
Acta Poloniae Historica

114,2016

PL ISSN 0001-6829

\section{Stefan Czarnowski}

\section{REDUNDANT PEOPLE IN THE SERVICE OF VIOLENCE}

It is an accurate albeit simplistic idea that the petit bourgeoisie, threatened by the progress of the proletariat, then produces the so-called mass foundation for fascism, a form of political system where the monopolistic aims of capitalism (as it stands now-a-days) are most fully expressed. Still, even after the necessary refinements and corrections to elevate this idea to the level of a theory, there remain unexamined conditions contributing to the triumph of fascism. As we know, fascism is capable of proving victorious even in countries abounding in an immeasurably numerous, class-conscious, perfectly organised, great-industrial proletariat. This is what we have witnessed in Germany.

Our intent here is not to consider all these conditions. Let us confine ourselves to discussing just one of them - the one which, in our opinion, is very important in terms of the raw human material out of which fascism forges instruments for battle and victory. Namely, it is the existence of a sufficiently numerous social 'margin' to use Thrasher's terminology ${ }^{1}$ - in other words, a sufficient number of declassed individuals who are without a defined social status and are, therefore, considered redundant from the standpoint of material and intellectual production and even in how they consider themselves.

The notion of the social margin ought not to be mistaken for the notion of the lumpen-proletariat. The margin extends to individuals or even entire groups who cannot possibly be regarded as the lumpenproletariat. Besides vagabonds and those living on casual labour, or

${ }^{1}$ Most likely Czarnowski refered to Frederic M. Thrasher, The Gang: A Study of 1,313 Gangs in Chicago (Chicago 1927). In this book Thrasher introduced the notion of gangland as a geographically and socially "interstitial to the more settled, more stable, and better organized portions of the city" (p. 22). As it is difficult to find a direct equivalent of the term 'interstitial' in Polish, Czarnowski spoke of the 'social margin' (margines spoteczny). 
mostly from charity, the margin includes professional criminals, along with honest people who, for whatever reason, colloquially speaking, 'cannot find a place for themselves in the world'. Thus, among them are young people from workers' families seeking jobs in vain, advanced school graduates from petit-bourgeois backgrounds who do not know what to do with their school diplomas, as well as the dispossessed ex-landowners from Ukraine seeking the patronage and assistance of wealthy relatives. Also belonging to the social margin are all those treated by the organised community as scroungers and intruders, who are slandered (at the very least) as having illegitimate ambition or inefficiency, or, not infrequently, accused of various improprieties, such as what is called 'wheeler-dealership', soliciting donations in the guise of loans, living on the border between honesty and criminality - in each case, a form of leeching off the social organism. Oh, how many accusations have we heard or read, targeting the unemployed: that they approach their social position as a profession, so that, whilst remaining jobless, they may live by the supposed grace of society! This, after all, in no way prevents the same organised community from maintaining a sense of pity towards social outcasts. Yet, the community demands of them that they recognize these "charitable works' and resents it when the beneficiaries put forward their own demands. It is enough to cite, as an example, the indignation of the press in Warsaw toward the 'stubbornness' of starving jobless men who dared consider midday meals dispensed to them as something to which they were entitled and expressed their dissatisfaction with the poor quality of distributed foodstuffs.

It is not our purpose here to closely examine the issue of the social margin's emergence. It suffices to state that such a margin exists in each society where the means of production are 'bound', that is, captured by a kinship group, an estate, the Church, or an exclusive organisation of producers, regardless of the degree of technical, constitutional, or spiritual development. In Central Africa a marginal man in the form of a tribesman who for any reason has lost his relation with his family village has no other means for survival other than yielding to slavery, whoever the master is. Pre-classical Greece had its thet, unbound and living on his own; personally free but, for the reason of that freedom, destitute of any rights, accepted for work in times of need and then driven away, often without getting paid - because, being a free and thus right-less man, he had no-one 
to complain to. The Middle Ages knew various categories of homines vagi, beginning with ordained priests who, having abandoned their bishop or monastery, sold fake relics and amulets at crossroads and would oftentimes join bandit gangs as chaplains, the so-called clerici acephali. Among other categories of homines vagi were peasant fugitives from their masters, knights whose lords had lost their wealth, and the younger brethren of feudal landowners, who offered their arms to anyone whose gang could offer opportunities for plunder. And in Poland we also had the lazegas (vagrants) or ludzie luźni - the homines vagi, or vagabonds of plebeian descent, as well as the gotota (landless nobility), who searched for opportunities to serve and often asked for alms. The 'deliberating estates' of the Sejm ineffectively attempted to subject these categories of people to the interests of the proprietor nobles; municipal guilds tried to obstruct their entry into town so that they would not drive down worker's pay; whilst the urban patriciate used these people many times to check the 'refractoriness' or impudence of the population of artisans.

In periods of stabilisation, these elements spend their lives on the margins of the community, living from hand to mouth; and, in spite of their exclusion, they are tolerated because they fulfill certain determined functions, which are considered necessary though they never enjoy recognition and sometimes are scorned outright. These functions are primarily socially unorganised services, of an occasional or private nature, or functions for which the community has not developed, nor managed to develop, any satisfactorily operating agencies or bodies. Such is the case, for instance, in a number of countries with respect to the safety of commodities transport: in China, and not only there, transports are entrusted to the care of robber gangs, who are obviously paid for the service - given the fact that police supervision is ineffective outside city limits. In Poland, Gypsies are a typically marginal social group. They are often accused of thievery, even of children and horses, the latter being so valuable for our peasants; accordingly, rural dwellers undertake special means of precaution whenever a Gypsy camp appears nearby. At the same time, their services as coppersmiths or boiler-makers, horse-doctors and fortune-tellers answer local demand. On the occasion of urgent needs for various kinds of seasonal agricultural work, such as haying, harvest, or vintage, the services of the people wandering across the country are willingly used. These same people are otherwise driven 
away and denounced to public security officials as dangerous or at least disreputable drifters.

In the United States, gangsters are hired during general election periods to smash rallies or give political opponents a beating. We are aware that this is the case also in a number of European countries, and that in any large city including Warsaw, there are some taprooms where one can hire men to deliver private vengeance at any time. The intermittent services of the aforementioned elements, who find it hard to establish themselves in the world, are all the more frequently taken advantage of - often with an honest purpose in view, where developing a formal authority is not worth the effort. Examples seem unnecessary: each of us know of some people without permanent employment, socially not-classified, who earn their living rendering sporadic small services, such as keeping a place in line for somebody whose time is valuable, getting parcels to where they need to go, or opening car doors and unfolding umbrellas for well-dressed ladies getting out of the car.

Such is the case in times colloquially referred to as normal. However, in periods of great social and political change, we can see that the marginal elements gain enormously in importance, on one hand, as they multiply in number, and, on the other hand, as they become organised by capable forces who have the resources at their disposal to turn marginal elements into a battering ram to smash the established order.

History abounds with drastic examples of the great role which in peculiar moments marginal people have played after having been forcefully or voluntarily drawn into service of, let's say, entrepreneurs of political and economic change, a diverse group of unscrupulous seizers of power and territory. These outcasts are drawn into the service of the wealth-amassing classes who need an instrument with which to break the existing system into pieces and establish their own violent forces. Whose arms were used to carry out the Spanish crusade against the Moors? Did they not belong to the 'cadets' from French feudal houses who, with not a penny in their pocket nor oftentimes even their own armour or a horse of their own, came running from everywhere to join under the banners of the kings of Aragon, Castile, León, or of the counts of Barcelona, because they were invigorated by the hope to win spoils of war and - if they were lucky enough - to receive a wealthy feoff in the conquered lands? For many a 'cadet', 
the crusade was merely a great venture for the sake of which they had quit their daily job of robbery. The mercenary armies, that were used by thirteenth- and fourteenth-century rulers as a tool for breaking the resistance of the broad mass of tributaries and for laying the foundations of the edifice of absolute royal or ducal authority, were similarly composed of elements we refer to as 'marginal'. One could find everything amidst the ranks of a gran' compagnie: a vagabond; a professional thief; a fratello who has escaped from his monastery; a subject who, having abandoned his land and lord, has gone out to the wider world; a wandering textile worker who has grown weary of his work; an apprentice who has severed relations with his guild; a landless (gotota) nobleman; all in all, everything except for socially established people. Even among the commanders one meets at times similar people, one example being the famous Giovanni Acuto - that is, Jean de l'Aiguille, who was active in Italy spearheading an international team of soldiers: this English condottiere had once quit his original profession as a tailor in favour of a more profitable warfare and predatory enterprise. It is not at all necessary to underline that the line between this period's troops put at the service of one ruler or another and a gang of ruffians is rather fine. Such mercenary hirelings were called routiers in France not for nothing: 'people of the road' meant those who have been recruited among roamers and brigands brawling their way along the public roads. And it is not for nothing that the term 'condottiere', meaning a commander of an armed group renting his service, is equivalent to a 'lease-holding entrepreneur'. Offered an agreed-upon sum of money and an opportunity to plunder, a condottiere undertakes to execute a specific war performance, just as in our day a leader of a gangster crew undertakes the beating of an opposition party candidate's followers. Such men were instruments used under the authority of despots at the turn of the fourteenth century, like Philippe the Fair of France or Edward of England. It was exactly the same sort of people who were led to battle by the 'Black Prince', who crushed the might of local lords and the French realm in Guyenne and Gascony. And what of the Italian tyrants? Most of these 'princes' (principi) were rich lords who had crushed the republican communes with the power of mercenary squads. More often, though, they were simply condottieri who had served the cities' republicans until the moment they came to believe that it would be more convenient for them if they themselves became unrestricted rulers over the cities. 
In all the cases referred to, and in those (considerably more numerous ones) that might moreover be cited, we have to deal with very diverse elements as far as it concerns their background and nature, however the situation is formally identical in their relationship to the organised centres of a regular, or at least fairly stabilised, community. 'Marginality' is their shared feature and, in a formal approach, we deal with one general phenomenon, describable as a process of more or less violent reintegration of marginal elements into the group as organised by forces who are striving to expand their power and consolidate their rule. This is, indeed, an instance of reintegration, by creating space within a community for those who have had no recognised place therein ever before. Such was the case with military reforms pursued by Marius, which led to the replacement of the civic army normally formed in wartime, by a permanent army composed also of citizens who were indigent however and, therefore, enlisted for the sake of soldier's pay and a retirement pension. Ever since, military service became a profession in the Roman state, and the army became a tool the emperors used to crush the republic. There is one more notable observation: in all the cases we know of, the use of marginal people in smashing the previous status quo was preceded by a period of very intensive numerical multiplication of people on the social margins. Without reconsidering the historical reasons for this multiplication, we note only that it took place in conjunction with this aforementioned relationship: the monopolisation of the means of production and the restriction of the right to perform one's profession to the privileged classes.

We are presently undergoing a period of similar monopolisation and a similar, and very intense, multiplication of the social margin. Capitalist monopolisation has received extensive coverage in the literature, so we can consider ourselves excused for not discussing the issue in this short article. It suffices to note that in the area of our present interest, capitalist monopolisation manifests itself in the sustained exclusion of enormous masses from productive labour. Cartelisation leads to workshops getting closed down in the name of removing competitors. Rationalisation leads to limiting the numbers of workers. As a result, enormous masses of jobless people lose any hope for ever finding any sort of employment, and the youth, increasingly numerous year by year, find all doors closed before them. While young people are not regarded as unemployed - not included among 
those who have lost their jobs since these young people have never managed to start any work whatsoever - they are readily classed as 'redundant'. According to our tentative calculation, the number of youth ages 16 to 25 , incapable of finding a place for themselves under the sun, will reach up to 1.5 million in five years' time in Poland alone. Such is the case only with those young people whose families have no established foundation of subsistence apart from manual labour or intellectual work. This is exceedingly more than the labour market could have absorbed even in the best conditions, comprehending that new generations will keep growing up. Meanwhile, regardless of the crisis which is not only situation-dependent but structural too, the development of present-day capitalism clearly trends toward an increasingly limited number of labour forces.

What we have to do with at this point is something completely different from either preserving a 'stand-by army of labour' that weighs upon the working fraction of the proletariat or facilitating the bourgeoisie's manoeuvres. What we have to deal with, namely, is the exclusion of the masses outside the bracket of the organised production-oriented group. What's more, one can boldly say that the point is a conscious policy of aiming at supplying fascism - rather than production - with disposable hands for use at the appropriate moment. We are observing some very telling moves, about which we will only mention those taking place in two areas: social insurance and education.

We are all well aware of the long-standing and increasingly intensive campaign started against unemployment insurance. Leaving financial arguments aside, we are only concerned with the fact that depriving a jobless individual of an allowance or reducing the rate to ridiculously small amounts inevitably leads to social demoralisation among the great masses of the unemployed. Research conducted in the West, which is not suspected of being biased in favour of the proletariat, has provided evidence that the average unemployed person considers him or herself a regular member of society, and not as socially diminished in one's own eyes as long as one receives an allowance not as alms but as an entitlement. In the case of losing the unemployment allowance, one very soon becomes a person who considers one's self outside the law, a redundant and scorned human being. An individual loses any sense of solidarity, even class solidarity, detesting everything and everybody and envying former workmates who did not lose their jobs. 
One then becomes a detached individual, secluded amidst a crowd of similar individuals. Even faster, young people similarly become detached, like leaves from a tree tossed by the wind. They become a burden at home and often face the reproach that they are doing nothing. Nobody is willing to offer them employment. They do not have the means and nor the opportunities to learn or improve their skills. Extending the period of compulsory schooling and providing the financial resources necessary to satisfy this obligation would doubtlessly help protect the youth from early expulsion onto the streets while also diminishing the pressure they exert on the working proletariat. It is not for nothing that the International Labour Office and a number of workers', employees' and teachers' congresses have called for the extension of compulsory education and material aid to parents incurring a studying child's cost of living. What we are witnessing, though, is the implementation of school reforms that have resulted in a factual reduced period of education and the factual prevention of the wider masses from attaining a higher level of education. A whole range of schools with seven grade levels have been replaced by schools with four grades; junior high schools [gimnazjums] have lost their two highest grades to senior high schools [liceums]; as a result, a considerable fraction of young people with a secondary education will start seeking work earlier than before. The tendencies are to reduce the period of study at schools of higher education, which must lead to a larger number of graduates seeking work.

There is also a desire to limit the alleged overproduction of intelligentsia, which has already been reflected in limiting the number of admissions to many schools of higher education or to some of their faculties. As a result, a huge number of people have deviated or otherwise gone astray. Those, who once prepared themselves for higher education, were not admitted, and not being prepared for a practical life, nor having any profession, now run around seeking support from their acquaintances. In the name of restricting competition in technical, juridical, or medical professions, the number of declassed individuals gets multiplied; those who have graduated from lower, secondary, or higher education schools are offered unpaid internships and are afterwards replaced by other cost-free trainees.

These matters are too well known to make dwelling on them worthwhile. We are eyewitnesses to the formation of an army of derelicts, descending from the peasantry, the working-class, and 
the intelligentsia. The enormous, ever increasing, margin that to a growing extent, consists of young people full of youthful temper, has been inclined to generate in themselves an 'inferior value complex', and craves recognition for how they rank in contrast to those who have work, earn their own money, and enjoy public respect. Such people are necessary for fascism. It is among them that fascism recruits its armed gangs, its black-, brown-, or otherwise coloured shirts. Italian fascism organised the fighting squadrons that beat and dispersed factory-seizing workers from nowhere else but among unfinished students, hopeless candidates for government-service posts, and, particularly, the reservists demobilised after the war who - after several years spent in the battlefield trenches, had lost the habit of working but remained accustomed to discipline - found their work-benches occupied. It is also a known fact that Nazism, before the 1933 takeover, primarily organised unemployed young people who had no hope to find any employment whatsoever. Several court trials (which, clearly enough, were held before Hitler seized power) have revealed the composition of assault troops as well as their typical training methods. Those young men had parents with varied backgrounds: intellectuals, private officials, petty craftsmen, and quite a number of workers. The storm-troopers, each and every one of them, were young men without a defined job or occupation, who hung around the city looking for love affairs, street brawls and, possibly, some adventitious financial gain or food and drink. Some were permanent dwellers of homeless shelters; others, particularly if born into an intelligentsia family, got their feet wet as professional pimps; others still, a majority of them, were young lads who had found the reproaches they heard at home about their being a burden abominable, and had lost any hope that it would be worthwhile to try to find work. Assault troops became particularly alluring for these young men. Moving forward at first it meant a warm spot in a separate room within a public house with food and drink offered almost on a daily basis by more-well-off political friends who on their visit to the taproom considered it their duty to provide the brave assault-trooper with a pint of beer and at times a sandwich. Lastly, and primarily - apart from several dozen pfennigs of 'soldier's pay' from the organisation - it provided the feeling that you were partaking in some important matters, the ambience of collective self-praise, emblazoning oneself with advantages achieved over the 'commune', and, last but 
not least, the excitement of awaiting a collective 'action': a street fight or a raid. It was these military groups, consisting in significant part of sons of the proletariat, who were repeatedly thrown upon workers' districts where they perpetrated massacres. And they joined these expeditions with enthusiasm. The sense of class solidarity had faded out of them, only a hatred towards the employed 'wonder boys' smouldered in them, and they were animated instead by the feeling of solidarity among members of a single gang. Quite similar to the historic examples cited above, the brutish soldiers of a peasant's or artisan's background took pleasure in the pillaging and hanging of other craftsmen and peasants.

The point is not, therefore, that the organised proletariat and the working classes in general under the right conditions will lack the means to oppose the fascists, or even immobilise the game they play. Nevertheless, they should be aware of this game. The subject of this essay was to point out to one of the trump cards in this game - in our opinion, not the least important one.

trans. Tristan Korecki

copyediting Aaron Law

First published in Gtos Wspótczesny, i (1935), 1-8. 